\title{
Phylogenetic Relationships of Mastomys to Mouse and Rat Deduced from Satellite DNA Sequences
}

\author{
Hisashi HISATOMI, Ryuichi MIURA*, Kunio SHIOTA*, Tomoya OGAWA*, \\ Kazutoshi SAYAMA**, Shin TANAKA***, Akio MATSUZAWA***, \\ and Yasuhiko KANOH \\ Department of Animal Physiology, Faculty of Agriculture, Meiji University, 1-1-1 Higashi-mita, \\ Tama-ku, Kawasaki-shi, Kanagawa 214, *Laboratory of Cellullar Biochemistry, Veterinary \\ Medical Science/Animal Resouce Science, The University of Tokyo, 1-1-1 Yayoi, \\ Bunkyo-ku, Tokyo 113, **Department of Animal Science, Faculty of \\ Agriculture, Shizuoka University, 863 Ohya, Shizuoka-shi, \\ Shizuoka 422, and ${ }^{* * *}$ Laboratory Animal Research Center, \\ Institute of Medical Science, The University of \\ Tokyo, 4-6-1 Shirokanedai, Minato-ku, \\ Tokyo 108, Japan
}

(Received 14 December 1993/Accepted 12 April 1994)

\begin{abstract}
Mastomys is a rodent with a intermediate size between mouse and rat, and classify as a subgenus of Praomys coucha. Our study determined the phylogenetic evolutional relationships of mastomys to mouse and rat deduced from satellite DNA sequences. Genomic DNA was extracted from each liver and digested by restriction enzymes (EcoRI and $B g l \mathrm{II}$ ) . After separation and purification, we obtained these $E c o \mathrm{RI} / B g l \mathrm{II}-0.5 \mathrm{Kbp}$ repeated elements and determined the nucleotide sequences. The similarities and speed of evolution were $86.06 \%$ and 0.1578 between mastomys and mouse, $85.56 \%$ and 0.1671 between mastomys and rat, and $83.91 \%$ and 0.1863 between rat and mouse, indicating that mastomys was evolutionary classified between mouse and rat, and closely related with mouse. - KEY WORDS : mastomys, phylogenetic relationship, satellite DNA, sequence
\end{abstract}

\section{サテライト DNA 配列から推定したマストミスのマウスおよび ラットとの類縁関係}

久富 寿 • 三浦竜一*・塩田邦郎* 一小川智也*・茶山和敏**・ 田中 壃***・松沢昭雄***・加納康彦

明治大学農学部動物生理学研究室

*東京大学農学部獣医学科獣医生化学研究室

***静岡大学農学部応用生物化学科

***東京大学医科学研究所実験動物施設

マストミス (Praomys coucha) はマウスとラットの 中間大の大きさをもつネズミ科のプラオミス属に属す るアフリカ原産の代表的なげっ歯類である $[12,15]$ 。 マストミスの実験動物としての歷史は比較的浅く,
1950年代前半からペスト，ラッサウイルス，住血吸虫 に高感受性の感性動物として利用されはじめた $[6]$ 。 その後, 胃, 肝荿, 副腎, 胸腺, 脳下垂体, 前立腺, 卵巣などの腫瘍が報告され，多くの荿器組織に各種の 
腫瘍をかなり高率に自然発生する実験動物として重要 な位置を占めることとなった。さらに一部の変異系の 近交化の過程で，七トを除いて唯一，胃に腺癌が自然 発生する哺乳類でもある [15]。

他のげっ歯類（ラット，マウス）と比較した場合, その解剖学的な特徴として以下のことが上げられる。 マストミスはラットと同椂胆串を欠き，雌にも前立腺 が存在する。副堅皮質では三者にそれぞれ特異な付加 層が確認され，マストミスの境界層は極めて特徴的な 変化を示す $[13,14]$ 。また，妊娠期間はラットと同様 23日であるが，産子数はマウスと同し 7 匹前後で，乳 腺数はマウスおよびラットが 6 対以下であるのに対 し，マストミスは 7 対以上存在する。このような解剖 学上の相違から，マストミスは分類学および系統発生 学でマウスおよびラットのいずれに近縁か未だ明確な 結論には至っていない。

従来, 分類学上や系統発生学上での近縁関係を明ら かにするための手がかりは, 生物の形態学的な比較や 解剖学的特幑の比較を中心とした研究によって扱われ てきたが，近年の遺伝子工学の進歩に伴い，遺伝子の 一次構造の比較を基にした系統樹の作成および類縁関 係の決定がなされるようになった。遺伝子DNA は進 化の過程で変異が起こりにくく，近縁の生物間におい てそれほど大きな変異が見られないため，このような 系統樹の作成および類縁関係の決定には, 自然淘汰の 影響を受けないで变異の蓄積したミトコンドリア DNA や非遺伝子DNA が用いられてきた。非遺伝子 DNAの中でも, ゲノム DNA から様々な制限酵素に よる消化で作出されるサテライト DNA は多くの染色 体上にまたがって数多く反復して存在し，親子鑑別の プローブやこうした一次構造の比較に用いられてき た。マウス $[1-3,5,8]$ やラット $[4,11]$ ではこれまで 数多くのサテライトDNAの一次構造が決定さてい る。

本研究では，マストミスのマウスおよびラットとの 分類学的および系統発生学的関係を解明するために, 三者の類似性の高いBam HI ファミリーのサテライト DNAの一次構造を決定し, それら一次構造の相同性 探査を行った。

\section{材料および方法}

1）使用動物：マストミスは米国立衛生研究所 (NIH) 由来で東北大学, 東京大学医科学研究所で近
交化され[15]，1985年に明治大学動物生理学研究室に 導入された $F_{36}$ の個体を兄妹交配で維持し， $F_{56}$ に至っ た 9 週龄の個体（雄 5 匹，雌 5 匹）を用いた。マウス は日本クレアから購入した 9 週㱓の $\mathrm{BALB} / \mathrm{cA} \mathrm{Jcl}$ (雄 5 匹, 雌 5 匹), ラットは三協ラボサービスから購 入した 9 週秢のクローズドコロニーである Wistar/ $\mathrm{ST}$ (雄 5 匹，雌 5 匹)，チャイニーズハムスターは三協 ラボサービスから購入した 9 週䑪の個体（雄 5 匹，雌 5 匹) を用いた。

2) ゲノム DNA の抽出：使用動物から肝荿 $1 \mathrm{~g}$ を 摘出し，ただちに $5 \mathrm{m \ell}$ のホモジナイズ溶液 $(10 \mathrm{mM}$ Tris-Cl pH7.5, 0.1 M NaCl, $1.5 \mathrm{mM} \mathrm{MgCl}_{2}$ ) を加 え, $4{ }^{\circ} \mathrm{C} \cdot 3000 \mathrm{rpm} \cdot 2$ 分間ホモジナイズした (Omega Electric Homogenizer, TypeSW-3)。得られたホモ ジネイトを $4{ }^{\circ} \mathrm{C} \cdot 3000 \mathrm{rpm} \cdot 10$ 分間で遠心 (Kubota KN70）したのち沈殿物を STE 溶液（10 mM Tris-Cl

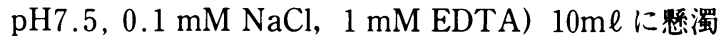
した。10\% SDSを $1 \mathrm{~m} \ell$ 加えて細胞成分を可溶化し た。プロティナーゼ $\mathrm{K}(10 \mathrm{mg} / \mathrm{m} \ell) 200 \mu 1$ を加え $50^{\circ} \mathrm{C}$ ・ 12時間インキュベートしてタンパク質成分を分解し た。インキュベート後, 等量のフェノール溶液（飽和 フェノール/クロロホルム/イソアミルアルコール $25: 24: 1)$ を加之, 10 分間振とう後, $4{ }^{\circ} \mathrm{C} \cdot 3500 \mathrm{rpm}$. 10分間遠心し， 2 回繰り返した。上清をクロロホルム 抽出を行い， $-20^{\circ} \mathrm{C}$ の $100 \%$ エタノールを 3 倍量加え DNA を沈殿させた。沈殿を $70 \%$ エタールで洗い, 乾 燥させた後, TE 溶液 $(20 \mathrm{mM}$ Tris-Cl pH7.5, $1 \mathrm{mM}$ EDTA pH8.0) に溶解した。

3 ）サテライトDNAの単離：抽出したゲノム DNA を制限酵素EcoRI（Takara 社製）にて消化し た。の後, TAE ( $40 \mathrm{mM}$ Tris-acetate, $2 \mathrm{mM}$ EDTA $\mathrm{pH} 8.0)$ に溶解した $1 \%$ アガロースゲル電気泳動を行 った。電気泳動によって分離したマストミス, マウス およびラットの約1350bpのサテライト DNAを EASYTRAP (Takara 社製) で精製した。この DNA 断片をさらに制限酵素 BglII (Takara 社製)で消化し， 同樣に電気泳動後，約 $500 \mathrm{bp}$ のサテライト DNA 断片 を精製した。

4 ) サテライトDNA の塩基配列決定：マストミス, マウスおよびラットに共通して見られた約500bp のサ テライト DNA 断片を制限酵素BamHI (Takara 社. 製) で切断したプラスミドべクター pUC119にDNA Ligation Kit (Takara 社製)を用いて Ligation した。 得られた pUC119組換えプラスミドを E . coli（X11- 
Blue 株)のコンピテント細胞に形質転換した。さらに, 形質転換された組換え体から, M13 Helper phage に よって一本鎖 DNA を調整した $[9]$ 。調整した一本鎖 DNA を Auto Read Sequencing Kit（ファルマシア社 製）とALF DNA Sequencer（ファルマシア社製）を 用いて，塩基配列の決定を行った。

5 ) マストミスの類縁関係の決定 : 得られた塩基配 列からマストミス，マウスおよびラットの分岐年代の 差異を推定するために Kimuraの式 [7] を参照した。 まず，マストミスとマウス，マストミスとラット，マ ウスとラットそれぞれの塩基配列の「違い」の数を求 めた。そのうち, 塩基の転位型の違いを $\mathrm{P}$, 塩基の転 換型の違いを $\mathrm{Q}$ として以下の式から進化速度を求め た。 $\mathrm{K}=-1 / 2 \log _{\mathrm{e}}\{(1-2 \mathrm{P} /$ 総塩基数 $-\mathrm{Q} /$ 総 塩基数) $\sqrt{1-2 \mathrm{Q} / \text { 総塩基数 }}\}$ さらに, 求められた Kの值から系統樹を作成した。また，得られた塩基配 列からマストミスとマウス，マストミスとラット，マ ウスとラットそれぞれの相同性を算出した。

\section{成 績}

マストミス，マウス，ラットおよびチャイニーズハ ムスターから抽出したゲノム DNAを制限酵素 $E c o$ RI 消化後得られた DNA 断片をアガロースゲル 電気泳動で分離した(Fig. 1)。マストミス，マウスお よびラットにおいて1350bpの DNA 断片が見られた のに対して，チャイニーズハムスターでは観察されな かった。この DNA 断片 (EcoRI-1.35Kbp repeated element)は，マウスではBam HI ファミリーあるいは L1Md ファミリー [4,5]，ラットではRat LINE [11] として既に報告されているサテライト DNA である。 マウス, ラットと同様の1.35Kbp の DNA 断片がマス トミスに存在することから，この断片がマストミスの サテライト DNA (EcoRI-1.35Kbp repeated element）である可能性が考えられた。

さらにアガロースゲル電気泳動で検出されたマスト ミス，マウスおよびラットのEcoRI-1.35 Kbp repeated element を制限醉素BglII でそれぞれ消化 し，電気泳動を行った(Fig. 2)。EcoRI-1.35Kbp repeated element を BglII 消化で作出される約 $500 \mathrm{bp}$ のサテライト DNA は，マウスおよびラットで特異的 に見られることが知られている $[4,11]$ 。マストミスに も同様の DNA 断片 (Eco RI/BglII-0.5Kbp repeated element）の存在が明らかになった。

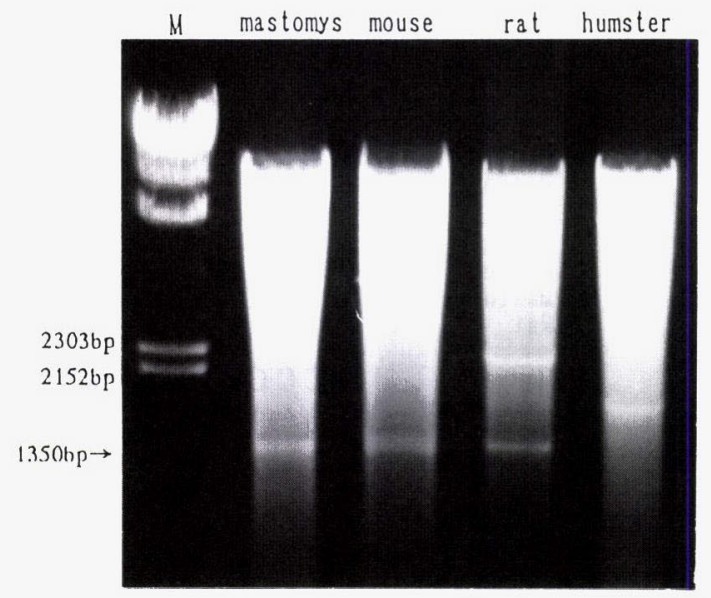

Fig. 1. Eco RI-1.35 kbp repeated elements from mastomys, mouse, rat and hamster in $1 \%$ agarose gel stained by ethidium bromide. Arrow shows 1.35 kbp of the DNA. $M$ (Marker)

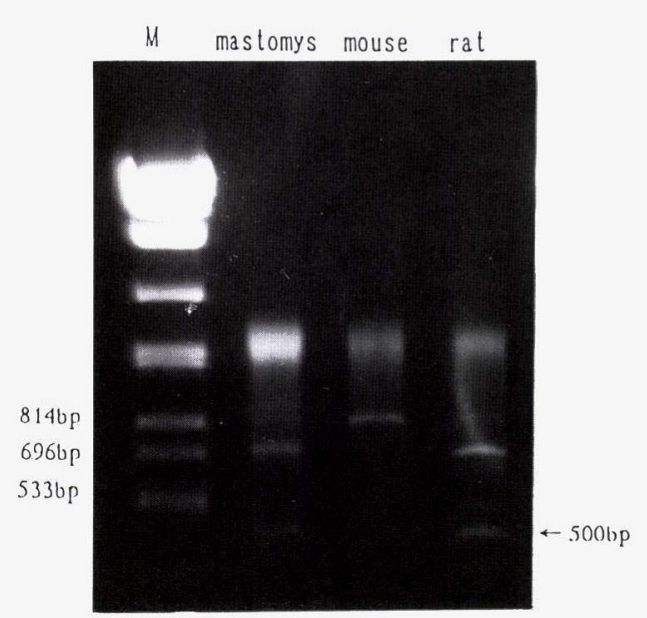

Fig. 2. Eco RI/BglII-0.5 kbp repeated elements from mastomys, mouse and rat in $1 \%$ agarose gel stained by ethidium bromide. Arrow shows $0.5 \mathrm{kbp}$ of the DNA. $M$ (Marker)

マストミス，マウスおよびラットの $E c o$ RI/Bg/II$0.5 \mathrm{Kbp}$ repeated element を詳細に比較するために, それぞれの DNA 断片の塩基配列を決定し（Fig. 3)， それぞれの相同性を計算した(Table 1)。マストミス とマウスの EcoRI/BglII-0.5 Kbp repeated element の相同性は $86.05 \% ，$ マストミスとラットでは $85.56 \%$ であることから，マストミスのEcoRI-1.35 Kbp 


\begin{tabular}{|c|c|c|c|}
\hline $\begin{array}{l}\text { Mouse } \\
\text { Mastomys }\end{array}$ & $\begin{array}{l}1 \text { GAАТТСААG } \\
1: \therefore\end{array}$ & $\begin{array}{l}\text { CCCATACCTA } \\
\therefore t \therefore \therefore t=g\end{array}$ & $\therefore \therefore$ a \\
\hline $\begin{array}{l}\text { se } \\
\text { loniys }\end{array}$ & $\begin{array}{l}31 \text { A AGCAATC } \\
31: \therefore \cdot \therefore a \\
31: \therefore \therefore\end{array}$ & $\begin{array}{l}C \wedge G \subset \wedge A A C C \\
\therefore a\end{array}$ & $\begin{array}{l}G \text { TACСAACA } \\
\therefore t: t \cdots\end{array}$ \\
\hline $\begin{array}{l}\text { se } \\
\text { slomys }\end{array}$ & 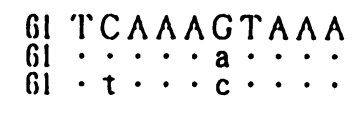 & $\begin{array}{l}\text { TGGGAGAAG } \\
\therefore a \\
\therefore a \\
a\end{array}$ & $\begin{array}{l}\text { CTGGAAGCAA } \\
\therefore t \therefore\end{array}$ \\
\hline $\begin{array}{l}\text { Mouse } \\
\text { Mas lomys }\end{array}$ & $\begin{array}{ll}9 & T \\
9 & 0 \\
91 & \cdot\end{array}$ & $\begin{array}{l}A T C \wedge G G A \wedge \\
\therefore \therefore \mathrm{g}\end{array}$ & $\begin{array}{l}\text { A GACAАGGCT } \\
\text { с а } \therefore \text { с } \therefore\end{array}$ \\
\hline $\begin{array}{l}\text { e } \\
\text { omys }\end{array}$ & $\frac{1}{1}$ & $\begin{array}{l}\text { ТССАТАСС } \\
\therefore \mathrm{C}: \therefore \mathrm{t}\end{array}$ & $\begin{array}{l}\text { TТСAACATAG } \\
\therefore \therefore t: c t:\end{array}$ \\
\hline tomys & ? & $\begin{array}{l}\text { стАGTCAGA } \\
t \therefore c: \therefore t\end{array}$ & $\begin{array}{l}\text { GCATT } \\
\therefore \therefore \mathrm{C}\end{array}$ \\
\hline $\begin{array}{l}\text { use } \\
\text { slomys } \\
t\end{array}$ & $\begin{array}{l}181 \text { A } \\
181: \\
181 .\end{array}$ & $\begin{array}{l}\text { GATСAAGGGG } \\
\therefore \therefore \text { a }\end{array}$ & $\begin{array}{l}\mathrm{AT} A \mathrm{CAAA} \\
\therefore \therefore \mathrm{gt}\end{array}$ \\
\hline $\begin{array}{l}\text { louse } \\
\text { laslomys } \\
\text { al }\end{array}$ & $\begin{array}{l}211 \mathrm{GA \wedge AAGA} \\
211 \div \therefore \mathrm{g} \\
211 . \cdots\end{array}$ & 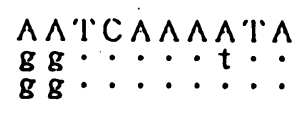 & 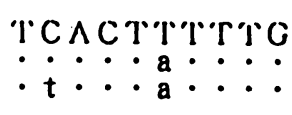 \\
\hline $\begin{array}{l}\text { use } \\
\text { stomys }\end{array}$ & $\begin{array}{l}211 \mathrm{C} \\
211 \\
241\end{array}$ & $\begin{array}{l}A T A T \\
\therefore \therefore C\end{array}$ & $\begin{array}{c}\text { ATAAGTGA } \\
\mathrm{t}: \therefore \\
\mathrm{t} \cdots\end{array}$ \\
\hline $\begin{array}{l}\text { Mouse } \\
\text { Maslomys } \\
\text { Ral }\end{array}$ & $\begin{array}{l}271 \mathrm{CT} \\
266: \mathrm{c} \\
271 \cdot \mathrm{c}\end{array}$ & $\begin{array}{c}\text { CACСАGAGAA } \\
\therefore \therefore g\end{array}$ & $\begin{array}{l}\text { CТССТАA } \\
\because a: \vdots\end{array}$ \\
\hline $\begin{array}{l}\text { Mouse } \\
\text { Maslomys } \\
\text { Ral }\end{array}$ & $\begin{array}{ll}301 & T \\
296 & \\
301\end{array}$ & 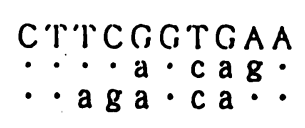 & $\begin{array}{l}\text { ATAGCTC } \\
\mathrm{g}: \mathrm{B}: \cdots\end{array}$ \\
\hline $\begin{array}{l}\text { Mouse } \\
\text { Mastomys } \\
\text { Rat }\end{array}$ & $\begin{array}{ll}331 & A \\
326 & : \\
331 & :\end{array}$ & СТСАААСАAG & $\begin{array}{l}\mathrm{T} C \mathrm{AA} \\
\because \therefore \mathrm{g} \\
\mathrm{g}\end{array}$ \\
\hline $\begin{array}{l}\text { Mouse } \\
\text { Maslomys } \\
\text { Ral }\end{array}$ & $\begin{array}{l}361 \cdot T^{\prime} \\
356 \cdot c \\
361 \cdot c\end{array}$ & $\begin{array}{l}\text { A A } \\
\therefore\end{array}$ & $\begin{array}{l}\text { CAGGCT } \\
\therefore a \cdot C\end{array}$ \\
\hline $\begin{array}{l}\text { Mouse } \\
\text { Maslomys } \\
\text { Ral }\end{array}$ & $\begin{array}{l}391: A \\
385: \\
391\end{array}$ & $\begin{array}{l}A C A A C A \\
\therefore: \therefore\end{array}$ & $\begin{array}{l}\text { ССТGСТСАA } \\
\therefore \text { t } \\
\therefore \text { at }\end{array}$ \\
\hline $\begin{array}{l}\text { Mouse } \\
\text { Maslomys } \\
\text { Rat }\end{array}$ & $\begin{array}{l}121 \mathrm{TAGTC} \\
115: \therefore \mathrm{t} \\
121 \cdot \cdots \mathrm{a}\end{array}$ & $\begin{array}{l}\text { TAC } \\
\square \mathrm{t}\end{array}$ & $\begin{array}{l}\text { TА ТTтGGTG } \\
\therefore c: \text { с }: \therefore\end{array}$ \\
\hline $\begin{array}{l}\text { Mouse } \\
\text { Maslomys } \\
\text { Ral }\end{array}$ & $\begin{array}{l}151 \mathrm{TGA} \\
415: \therefore \\
451 . .\end{array}$ & $\underset{\mathrm{a} a}{\square} \cdot$ & 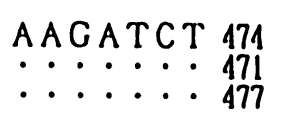 \\
\hline
\end{tabular}

Fig. 3. Comparison of the nucleotide sequences of these Eco RI/BglII-0.5 Kbp repeated elements. Dot shows the same nucleotide as that of mouse. Space box shows deleted nucleotide. 
Table 1. Similarity and speed of evolution among mouse, mastomys and rat deduced from Eco RI $/ B g l$ II $-0.5 \mathrm{kbp}$ repeated elements.

\begin{tabular}{lcccc}
\hline & Similarity & $\mathrm{P}$ & $\mathrm{Q}$ & $\mathrm{K}$ \\
\hline mouse v.s. mastomys & $86.05 \%$ & 38 & 29 & 0.1578 \\
mastomys v.s. rat & $85.56 \%$ & 39 & 32 & 0.1671 \\
mouse v.s. rat & $83.91 \%$ & 47 & 31 & 0.1868 \\
\hline
\end{tabular}

$\mathrm{P}:$ Number of transition $\mathrm{O}:$ Number of transversion $\mathrm{K}:$ Speed of evolution.

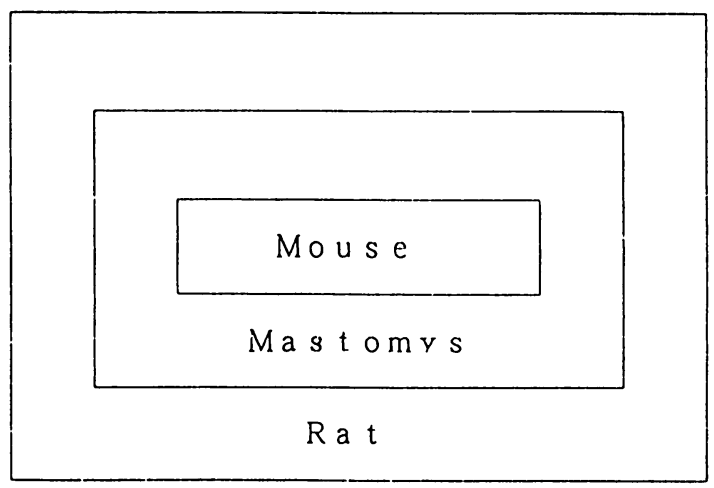

Fig. 4. Schematic presentation of homology of sequence among mouse, mastomys and rat

repeated element およびEco RI/BglII -0.5 Kbp repeated element はサテライトDNAであることが 明らかになった。さらに, マウスおよびラットには見 られない欠失部位(マストミス242-248), マウスには 見られない挿入部位（マストミス454-456, ラット 460-462) が存在していた。

マストミス，マウスおよびラットの EcoRI/BglII$0.5 \mathrm{Kbp}$ repeated element の塩基配列から進化速度 を算出した (Table 1)。マストミスとマウスの進化速 度は0.1578, マストミスとラットの進化速度は0.1671， マウスとラットの進化速度は0.1868であることからマ ストミスは系統的にみてマウスとラットの中間に位置 し(Fig. 4)，マウスに近い種であることが明らかにな った。

\section{考案}

本研究では, マストミスにおいてサテライト DNAEco RI/BglII-0.5 Kbp repeated element し，その塩基配列を決定した。その結果，マウスおよ
びラットにおける $E c o$ RI/BglII-0.5 Kbp repeated element と高い相同性を示し, マストミスは系統的に マウスとラットの中間に位置し, マウスに近いことが 進化速度の比較から明らかになった。

ゲノム DNA から制限酵素 Eco RI の消化によって 作出されるサテライト DNA は1980年代から解析さ れ, マウスおよびラットにおいては, 既にその塩基配 列が決定され，それぞれの種に普遍的な，約 $1350 \mathrm{bp}$ を 1 単位とする反復配列であることが知られている [1]。 マストミスから作出された EcoRI-1.35Kbp repeated elementの一部である $E c o$ RI/BglII -0.5 Kbp repeated elementもマウス, ラットのサテライト DNA との相同性を比較した結果から反復配列である と推測された。

マストミスがラットよりマウスにやや近緑であるこ とはこれまで, 腎臓 IV 型コラーゲンの免度学的特性 から報告されていた $[10]$ が, 今回のサテライト DNA 分子の進化速度の比較から, 上り明確な系統発生学的 分類を行うことができ，マストミスはマウスおよびラ ットと共通の祖先を持つことが明確になった。 本研究で用いたマストミスのみをもってして，マス トミス (Praomys coucha) の全ての種において, $E c o$ RI/BglII-0.5 Kbp repeated element が普遍的と は言い難く, 特定の系統に特異的である可能性も危惧 される。しかし，マウスおよびラットのEcoRI-1.35 Kbp repeated element がそれぞれの種において普遍 的であることを考虑に入れると，マストミスにおいて も系統間で差異が確認される可能性は極めて低く, $E c o \mathrm{RI} / B g l \mathrm{II}-0.5 \mathrm{Kbp}$ repeated element の普遍性は 高いものと考えられる。

\section{要 約}

マストミス (Praomys coucha) はマウスとラットの 中間大の大きさをもつネズミ科のプラオミス属に属す るげっ歯類である。本研究では, サテライト DNA を用 いてマストミスのマウスおよびラットとの系統的近縁 関係を調べた。それぞれの肝荿から抽出した遺伝子を 制限酵素 $(E c o \mathrm{RI} \cdot B g l \mathrm{II})$ で処理し, Eco RI/BglII-0.5 Kbp repeated element 精製し，それらの塩基配列を 決定した。それらの塩基配列を相互に比較した時の相 同性と進化速度は, マストミスとマウスでは $86.06 \%$ ・ 0.1578 ， マストミスとラットでは85.56\%・0.1671，マ ウスとラットでは $83.91 \% \cdot 0.1863 を$ 示した。このこと 
から，マストミスは系統的にマウスとラットの中間に 位置し, マウスにより近縁であることが明らかになっ た。

\section{文献}

[1] Brown, A. and Ru Chih C. Huang (1982). Mouse EcoRI satellite DNA contains A sequence homologous to the long terminal repeat of the intracisternal a particle gene. Proc. Natl. Acad. Sci. USA, 79, 61236127.

[2] Brown, S. D. M. and Dover, G. (1981). Organization and evolutionary progress of a dispersed repetitive family of sequence in widely separated rodent genomes. J. Mol. Biol., 150, 441-466.

[3] Brown, S. D. M. and Piechaczyk, M. (1983). Insertion sequences and tandem repetitions as sources of variation in a dispersed repeat family. J. Mol. Biol., 165, 249-256.

[4] D'ambrosio, E., Waitzkin, S. D., Witney, F. R., Salemme, A., and Furano, A. V. (1986). Structure of highly repeated, long interspersed DNA family (LINE1 or L1Rn) of the rat. Mol. Cell. Biol., 6, 411 -424 .

[5] Gebhard, W., Meitinger, T., Hochtl, J., and Zachau, H. G. (1972). A new family of interspersed repetitive DNA sequences in the mouse genome. $J$. Mol. Biol., 157, 453-471.

[6] 細田 峻・熊沢平次 (1987)。マストミス（Y15突然変異 系) 一自然発生胃癌の動物モデル。実験医学, 5, 103-105.

７］木村資生(1984). DNA レベルでの進化距嚁と速度の推定. 分子進化学入門, pp. 16-23, 培風館, 東京.

[8] Kominami, R., Urano, Y., Mishima, Y., and Muramatsu, M. (1983). Novel repetitive sequence fam- ilies showing size and frequency polymorphism in the genomes of mice. J. Mol. Biol., 165, 209-228.

[9] Messing, J. and Vieira, J. (1982). A new pair of M13 vectors for selection either strand of a double digest restriction fragment. Gene, 19, 269-276.

[10] Sayama, K., Hashimoto, H., Sasaki, A., Oikawa, T., Tanaka, S., and Matsuzawa, A. (1991). Phylogenetic relationships among laboratory animals deduced from basement membrane type IV collagen antigens. Zool. Sci., 8, 359-369.

[11] Soares, M. B., Schon, E., and Efstratiadis, A. (1985). Rat LINE1 : The origin and evolution of a family of long interspersed middle repetitive DNA elements. J. Mol. Evol., 22, 117-133.

[12] Solleveid, H. A. (1987). The multimammate mouse. In The UFAW Handbook on the Care and Management of Laboratory Animals, 6 th edition, pp. 346359. Pool, T., (eds), Longman Scientific \& Technical, Both Press, Avon, Great Britain.

[13] Tanaka, S., Nozaki, M., Fujioka, T., and Matsuzawa, A. (1990). Adrenocortical zonation of inbred wild-coloured mastomys, Praomys coucha: a new border zone in the cortex of females. Lab. Anim., 24, 5 -13 .

[14] Tanaka, S., Nozaki, M., Fujioka, T., and Matsuzawa, A. (1991). Effects of lactation on the border zone formation in the female mastomys (Praomys coucha) adrenal cortex. Acta Anat., 141, 269-273.

[15] Tanaka, S., Nozaki, M., Maruyamauchi, T., Kaneko, T., Yamanouchi, K., Okugi, M., and Matsuzawa, A. (1988) . Laboratory strain of hamster, gerbil and mastomys maintained at the Institute of Medical Science, University of Tokyo.Jpn.J. Exp. Med., 58, 273-278. 